\title{
Energy reserves and accumulation of metals in the ground beetle Pterostichus oblongopunctatus from two metal-polluted gradients
}

\author{
Agnieszka J. Bednarska • Izabela Stachowicz • \\ Ligia Kuriańska
}

Received: 5 February 2012 / Accepted: 18 May 2012 /Published online: 6 June 2012

(C) The Author(s) 2012. This article is published with open access at Springerlink.com

\begin{abstract}
Living in an area chronically polluted with metals is usually associated with changes in the energy distribution in organisms due to increased energy expenses associated with detoxification and excretion processes. These expenses may be reflected in the available energy resources, such as lipids, carbohydrates, and proteins. In this context, the energy status of Pterostichus oblongopunctatus (Coleoptera: Carabidae) was studied in two metal pollution gradients near Olkusz and Miateczko Śląskie in southern Poland. Both regions are rich in metal ores, and the two largest Polish zinc smelters have been operating there since the 1970s. Beetles were collected from five sites at each gradient. Zinc and cadmium concentrations were measured in both the soil and the beetles. The possible reduction in energy reserves as a cost of detoxifying assimilated metals was evaluated biochemically by determining the total lipid, carbohydrates, and protein contents. At the most polluted sites, the $\mathrm{Zn}$ concentration in the soil organic layer reached $2,906 \mathrm{mg} / \mathrm{kg}$, and the $\mathrm{Cd}$ concentration reached $55 \mathrm{mg} / \mathrm{kg}$. Body $\mathrm{Zn}$ and $\mathrm{Cd}$ concentrations increased with increasing soil $\mathrm{Zn}$ and $\mathrm{Cd}$ concentrations ( $p=0.003$ and $p=0.0001$, respectively). However, no relationship between pollution level and energetic reserves was found. The results suggest that populations of P. oblongopunctatus inhabiting highly metal-polluted sites are able to survive without any serious impact on their energy reserves, though they obviously have to cope with elevated body metal concentrations.
\end{abstract}

Responsible editor: Vera Slaveykova

A. J. Bednarska $(\bowtie) \cdot$ I. Stachowicz $\cdot$ L. Kuriańska Institute of Environmental Sciences, Jagiellonian University, Gronostajowa 7,

30-387 Kraków, Poland

e-mail: a.bednarska@uj.edu.pl
Keywords Lipids $\cdot$ Carbohydrates $\cdot$ Proteins $\cdot$ Zinc . Cadmium $\cdot$ Carabids

\section{Introduction}

Metal-contaminated areas are found all over the world due to atmospheric deposition from smelters and other metallurgic processes, and the most contaminated areas are usually located up to several kilometers from the emission source. Metal pollution may have a drastic impact on ecosystems, and several studies have shown a reduced density of soil invertebrates in the vicinity of the emission source (e.g., Spurgeon and Hopkin 1999). On the other hand, some invertebrates can tolerate metal concentrations far above levels known to induce lethal effects in non-tolerant populations (Stürzenbaum et al. 1998). Viable populations of animals have been found at soil contamination levels much higher than the critical concentrations of metals established for soil or food in the laboratory (Posthuma and Van Straalen 1993). Such inconsistencies show that results derived from laboratory experiments cannot be extrapolated easily to expected field effects, and studies on field populations are crucial and necessary.

Living in an area chronically polluted with metals is usually associated with changes in the energy distribution of organisms due to increased energy expenses associated with detoxification processes (Sibly and Calow 1989). However, the energetic budget of an organism is restricted. The major share of energy is used for maintenance and only the surplus can be devoted to biomass production via growth and reproduction. Maintenance requirements increase in organisms living in polluted environments, resulting in a reduction of energy for growth and reproduction (Sibly and Calow 1989). Therefore, the total amount of energy 
available for maintenance, growth, and reproduction may provide a sensitive measure of stress in an organism. Although the significance of detoxification costs in an organism's energy budget and their effects on fitness has been the subject of many studies (Khalil et al. 1995; Laskowski et al. 1998), such costs were found directly in only a few studies (Rowe et al. 1998; Hopkins et al. 1999; Pook et al. 2009). Some indirect proof is available regarding the costs incurred by toxicant-resistant individuals, such as lower reproduction (Lagisz et al. 2002) or decreased tolerance to other stressors (Stone et al. 2001).

The difference between available energy reserves (based on the biochemical analysis of carbohydrates, lipids, and proteins) and energy consumption has been shown to be indicative of an organism's overall condition (De Coen and Janssen 2003a), and a decrease in the available energy reserves can be used as a biomarker of metal stress (ScottFordsmand and Weeks 2000). The majority of studies on energy budgets have been performed with aquatic organisms (De Coen and Janssen 1997; 2003a; 2003b; Verslycke et al. 2004a; Erk et al. 2008; Smolders et al. 2003). Reduced energy reserves were reported in a study of protein, glycogen, and lipid contents in isopods from terrestrial ecosystems (Donker 1992). Maryański et al. (2002) observed decreased energy reserves in beetles exposed to $\mathrm{Zn}$ - or $\mathrm{Cd}-$ contaminated food in the laboratory.

In terrestrial ecosystems, carabid beetles are one of the invertebrates most resistant to metals, and many carabid species inhabit highly contaminated areas (Skalski et al. 2011). Beetles may acquire metals from soil through dermal absorption (larvae) and feeding on contaminated food (larvae and adults), and as a species with low dispersal ability (Brunsting 1981) may be confined to local zones of pollution for multiple generations. At the same time, these beetles are poor metal accumulators (Laskowski and Maryański 1993; Butovsky 2011), which may be the result of efficient detoxification and excretion mechanisms (Janssen 1991; Kramarz 1999). However, individuals inhabiting chronically polluted environments appear to be less tolerant of additional environmental stressors, such as pesticide treatment or food deprivation, than individuals from uncontaminated areas (Stone et al. 2001). This observation is indirect evidence of the costs of living in a polluted environment, which may result from a restricted energy budget when the allocation of energy to stress resistance increases survival but leaves less energy for other processes. Thus, the cost of metal tolerance can be observed as reduced energy reserves in populations from polluted environments compared to reference populations. Because the response of an animal to stress is a complex reaction, which depends not only on the type of chemical but also the many internal and external factors, studying two or more gradients, each with a number of differently polluted sites, allows for more general conclusions and provides better control over possible confounding factors. In the present study, energy reserves and body metal concentrations were determined in field-collected ground beetles, Pterostichus oblongopunctatus (Coleoptera: Carabidae), in order to investigate the costs associated with inhabiting areas chronically polluted with metals.

\section{Materials and methods}

\section{Test organism}

The ground beetle P. oblongopunctatus (Coleoptera: Carabidae) is a widely distributed species in European woods and can be considered a typical representative of epigeic carnivorous insects. As a non-specialized carnivore, this beetle may potentially be exposed to elevated concentrations of toxins in its diet. The generation time is generally 1 year, though a small proportion of adults may live up to 3 years (Brunsting 1981).

\section{Research area and beetle sampling}

Adult beetles were collected from sites located along two metal pollution gradients, in the vicinity of zinc and lead smelters near Olkusz and Miasteczko Śląskie (gradients labeled OLK and MSL, respectively) in southern Poland. Five study sites along the OLK pollution gradient were established in an earlier study (Stefanowicz et al. 2008), and five study sites along the MSL gradient were established in the present study based upon metal concentrations in the soil organic layer (Table 1). The same unpolluted site was used for both gradients but was labeled by different metal concentrations in the soil organic layer; metal concentrations measured by Stefanowicz et al. (2008) were used for the OLK gradient unpolluted site, and metal concentrations measured by Tarasek (2011) were used for the MSL unpolluted site. Five samples of the whole soil organic layer were randomly taken from an area of approximately $100 \mathrm{~m}^{2}$ at each site on the OLK gradient, sieved (mesh size, $10 \mathrm{~mm}$ ), and mixed (Stefanowicz et al. 2008). Ten samples of the whole soil organic layer from each site along the MSL gradient were taken while trapping the ground beetles and analyzed as described by Stefanowicz et al. (2008) except that each sample was analyzed individually for chemical characteristics. The contamination levels at all sampling sites are reported as total zinc and cadmium concentrations in the soil organic layer, as well as a pollution index (see below). All sites at both pollution gradients were located in mixed Scots pine, Pinus sylvestris L., forests on sandy podsolized soils with a small admixture of other species, including oak and birch. 
Table 1 Concentrations of metals in soil organic layer and in the ground beetles $P$. oblongopuncatus (mean $\pm \mathrm{SD}$ ) and calculated pollution indices (PI) for beetles collected along two metal pollution gradients

\begin{tabular}{|c|c|c|c|c|c|c|c|}
\hline \multirow[t]{2}{*}{ Transect } & \multirow[t]{2}{*}{ Location } & \multirow[t]{2}{*}{$\begin{array}{l}\text { Distance from nearest } \\
\text { smelter }(\mathrm{km})\end{array}$} & \multicolumn{3}{|c|}{ Metals in soil organic layer ${ }^{\mathrm{a}}$} & \multicolumn{2}{|c|}{$\begin{array}{l}\text { Metals in beetles (number of beetles } \\
\text { analyzed in brackets) }\end{array}$} \\
\hline & & & $\begin{array}{l}\mathrm{Cd}(\mathrm{mg} / \mathrm{kg} \\
\text { dry wt) }\end{array}$ & $\begin{array}{l}\mathrm{Zn}(\mathrm{mg} / \mathrm{kg} \\
\text { dry wt) }\end{array}$ & PI & $\mathrm{Cd}(\mathrm{mg} / \mathrm{kg}$ dry wt) & $\mathrm{Zn}$ (mg/kg dry wt) \\
\hline OLK & $50^{\circ} 18^{\prime} \mathrm{N}, 19^{\circ} 29^{\prime} \mathrm{E}$ & 3.9 & 39.1 & 1763 & 21.3 & $1.6 \pm 1.11(24)$ & $107 \pm 15(23)$ \\
\hline OLK & $50^{\circ} 19^{\prime} \mathrm{N}, 19^{\circ} 30^{\prime} \mathrm{E}$ & 5.3 & 14.7 & 1253 & 10.7 & $1.6 \pm 0.97(24)$ & $103 \pm 10(23)$ \\
\hline OLK & $50^{\circ} 19^{\prime} \mathrm{N}, 19^{\circ} 32^{\prime} \mathrm{E}$ & 7.9 & 12.2 & 755 & 7.6 & $1.8 \pm 1.10(24)$ & $104 \pm 15(24)$ \\
\hline OLK & $50^{\circ} 25^{\prime} \mathrm{N}, 19^{\circ} 38^{\prime} \mathrm{E}$ & 19.6 & 4.03 & 224 & 2.4 & $0.6 \pm 0.48(23)$ & $99 \pm 90(24)$ \\
\hline Unpolluted site 2008 & $50^{\circ} 32^{\prime} \mathrm{N}, 19^{\circ} 39^{\prime} \mathrm{E}$ & 31.8 & 1.48 & 109 & 1.0 & $0.7 \pm 0.65(23)$ & $100 \pm 11(24)$ \\
\hline MSL & $50^{\circ} 29^{\prime} \mathrm{N}, 18^{\circ} 57^{\prime} \mathrm{E}$ & 2.1 & $52 \pm 10.6$ & $2684 \pm 689$ & 20.5 & $3.7 \pm 1.89(32)$ & $104 \pm 16(32)$ \\
\hline MSL & $50^{\circ} 31^{\prime} \mathrm{N}, 18^{\circ} 56^{\prime} \mathrm{E}$ & 2.6 & $55 \pm 12.1$ & $2906 \pm 726$ & 21.9 & $3.4 \pm 1.41(38)$ & $106 \pm 17(42)$ \\
\hline MSL & $50^{\circ} 31^{\prime} \mathrm{N}, 18^{\circ} 57^{\prime} \mathrm{E}$ & 3.3 & $36 \pm 10.1$ & $1886 \pm 520$ & 14.3 & $2.3 \pm 1.19(51)$ & $101 \pm 15(54)$ \\
\hline MSL & $50^{\circ} 34^{\prime} \mathrm{N}, 19^{\circ} 58^{\prime} \mathrm{E}$ & 8.7 & $4.8 \pm 2.3$ & $319 \pm 80$ & 2.1 & $0.9 \pm 0.44(35)$ & $100 \pm 15(36)$ \\
\hline Unpolluted site 2010 & $50^{\circ} 32^{\prime} \mathrm{N}, 19^{\circ} 39^{\prime} \mathrm{E}$ & 31.8 & $2.2 \pm 1.8$ & $155 \pm 28$ & 1.0 & $0.4 \pm 0.37(41)$ & $95 \pm 14(43)$ \\
\hline
\end{tabular}

Pollution indices were calculated according to the equation PI $=\frac{\mathrm{Zn}_{i} / \mathrm{Zn}_{U}+\mathrm{Cd}_{i} / \mathrm{Cd}_{U}}{\text {, where index } i \text { denotes site number, index }}$ unpolluted site, and metal symbols stand for their concentrations in soil organic layer (in milligrams per kilogram dry weight)

OLK Olkusz, MSL Miasteczko Śląskie

${ }^{a}$ Data for OLK gradient from Stefanowicz et al. (2008), no SD indicated as chemical analysis were performed on mixed samples

Beetles were sampled with pitfall traps (approximately $200 \mathrm{ml}$ capacity). Ninety traps were distributed per site in three lines of 30 cups each and emptied every second or third day between April 24 and May 15, 2008 (OLK) or in the same period in 2010 (MSL). The beetles were transported to the laboratory in plastic boxes with perforated lids and filled with litter from the collection sites. The beetles were separated by gender, placed individually in $30-\mathrm{ml}$ plastic vials, and kept in a climatic walk-in chamber $\left(20^{\circ} \mathrm{C}\right.$, $60 \%$ relative humidity, 16:8 light/dark photoperiod) for $24 \mathrm{~h}$ to void gut contents. The beetles were then weighed to the nearest $0.0001 \mathrm{~g}$ on an electronic balance (AS 160/C/2 Radwag, Poland), and at least 23 males from each site were frozen at $-20{ }^{\circ} \mathrm{C}$ for metals analysis. The beetles used for biochemical analysis (ten males per site) were frozen in liquid nitrogen and stored at $-80^{\circ} \mathrm{C}$.

\section{Energy reserves analysis}

Legs, elytra, and wings were carefully removed from each beetle using forceps and a scalpel. The remaining body parts of each individual organism were used for biochemical analyses. All samples were homogenized on ice using a PRO 200 mechanical homogenizer (Bioeko, Poland), and measurements were performed on 96-well plates (Sarstedt, USA) using the $\mu$ Quant spectrometer (Bio-TEK Instruments, USA). Each sample was analyzed twice or in triplicate.

The samples were homogenized on ice in $600 \mu \mathrm{l}$ of icecold distilled water and the homogenate used for total lipid, carbohydrate, and protein measurements (adapted from De Coen and Janssen 1997). To measure lipid content, $250 \mu \mathrm{l}$ chloroform, $250 \mu \mathrm{l}$ methanol, and $125 \mu \mathrm{l}$ Molecular Quality water (Sigma, USA) were added to $100 \mu \mathrm{l}$ of homogenate. After centrifugation $\left(1,000 \times g, 5 \mathrm{~min}, 20^{\circ} \mathrm{C}\right)$, the top phase was removed and $500 \mu \mathrm{H}_{2} \mathrm{SO}_{4}(98 \%$, POCH, Poland) added to $100 \mu \mathrm{l}$ of lipid extract. After mixing, the sample was charred at $200{ }^{\circ} \mathrm{C}$ for $15 \mathrm{~min}$, then cooled to room temperature, and $1.5 \mathrm{ml}$ of distilled water added. The total lipid content was determined by measuring the absorbance at $400 \mathrm{~nm}$ using triglyceride tripalmitin (Sigma, USA) as a standard.

To determine the total protein and carbohydrate content, $100 \mu \mathrm{l}$ of $15 \%$ trichloroacetic acid (TCA) was added to $300 \mu$ of homogenate and incubated at $-20^{\circ} \mathrm{C}$ for $10 \mathrm{~min}$. After centrifugation at $1,000 \times g$ for $10 \mathrm{~min}$ at $4{ }^{\circ} \mathrm{C}$, the supernatant was collected and the pellet washed with $100 \mu \mathrm{l}$ of $5 \%$ TCA, centrifuged again, and the supernatant fraction combined with the previous fraction for use in the total carbohydrate analysis. The remaining pellet was resuspended in $500 \mu \mathrm{l} \mathrm{NaOH}$, incubated at $60{ }^{\circ} \mathrm{C}$ for $30 \mathrm{~min}$, and neutralized with $300 \mu \mathrm{HCl}$. The total protein content was assessed using Bradford's reagent (Sigma, USA; Bradford 1976). The absorbance was measured at $592 \mathrm{~nm}$ using bovine serum albumin (Sigma, USA) as a standard. To determine the carbohydrate content of the supernatant fraction, $50 \mu 15 \%$ phenol and $200 \mu \mathrm{H}_{2} \mathrm{SO}_{4}$ was added to $50 \mu \mathrm{l}$ of supernatant and quantification performed by measuring absorbance at $492 \mathrm{~nm}$ against a standard curve of glucose (Sigma, USA); since glycogen is hydrolyzed to glucose in hot sulfuric acid, 
this methodology can be used to determine also glycogen (Kemp and Kits van Heijningen 1953). The different energy reserves for each individual were converted into energetic equivalents using the energy of combustion (Gnaiger 1983) and summed: $17.5 \mathrm{~kJ} / \mathrm{g}$ glycogen, $24 \mathrm{~kJ} / \mathrm{g}$ protein, and $39.5 \mathrm{~kJ} / \mathrm{g}$ lipids.

\section{Metal analysis}

Whole beetles were dried at $105{ }^{\circ} \mathrm{C}$ for $24 \mathrm{~h}$ to obtain the dry mass, weighed to the nearest $0.0001 \mathrm{~g}$, digested in $2 \mathrm{ml}$ nitric acid (65\% Suprapur $\mathrm{HNO}_{3}$, Merck), and diluted to $5 \mathrm{ml}$ with deionized water. Concentrations of zinc were analyzed by flame atomic absorption spectrometry (AAS, detection limit $0.011 \mathrm{mg} / \mathrm{l}$ ), and cadmium was analyzed by graphite furnace AAS (detection limit $0.024 \mu \mathrm{g} /$ l) (AAanalyst 800, Perkin-Elmer, USA). Three blanks and three reference samples (Certified Reference Material No 185-bovine liver (IRMM, Belgium) and Standard Reference Material No $1577 \mathrm{c}$ - bovine liver (NIST, USA), for OLK and MSL samples, respectively) were run to check the analytical precision. The measured concentrations were within $\pm 5 \%$ or $-30 \%$ of the certified reference value, for $\mathrm{Zn}$ and $\mathrm{Cd}$, respectively. Metal concentrations in beetles were expressed as milligram per kilogram of dry mass.

\section{Statistical analysis}

Prior to statistical analysis, extreme values with modified median absolute deviation scores greater than 3.5 were excluded and the data tested for deviation from normality using the Kolmogorov-Smirnov test. When this condition was not met, statistical analyses were performed on logtransformed data.

The total metal concentrations in soil organic layer were used for statistical analysis as the total concentrations of $\mathrm{Zn}$ and $\mathrm{Cd}$ were highly correlated with their water-soluble fractions ( $r=0.97, p<0.0001$ and $r=0.98, p<0.0001$, respectively; Person correlation analysis). Correlations between $\mathrm{Zn}$ and $\mathrm{Cd}$ concentrations in the soil and beetles were checked using Pearson correlation analysis. Because the levels of metals in the soil highly correlated with each other $(r=0.99, p<0.0001)$ and with body concentrations $(r=0.82$ to $0.94, p \leq 0.003$ ), the study sites were described with a single measure of pollution defined as a pollution index (PI):

$\mathrm{PI}=\frac{\mathrm{Zn}_{i} / \mathrm{Zn}_{U}+\mathrm{Cd}_{i} / \mathrm{Cd}_{U}}{2}$

where $i$ denotes site number, $U$ - the unpolluted site, and metal symbols denote their concentrations in soil.

Different metal concentrations for the same unpolluted site in 2008 and 2010 were used to take into account possible differences in soil sampling and metal analysis performed by different people. Simple regression analysis was performed to verify the effect of soil $\mathrm{Cd}$ and $\mathrm{Zn}$ pollution on body $\mathrm{Cd}$ and $\mathrm{Zn}$ concentrations.

Multiple linear regression analysis was used to select the variables that significantly affect total energy reserves and each component of the reserves (proteins, carbohydrates, and lipids) separately. The analysis was performed using average values from each study site as the concentrations of $\mathrm{Cd}$ and $\mathrm{Zn}$ could not be measured in the same animals in which energy reserves were assessed due to technical reasons. The independent variables in the model were the PI and average body mass. Average body masses were calculated for the beetles used in metal analyses and the beetles used in energy reserve analyses for each site. Body mass was incorporated into the model because earlier one-way analysis of variance revealed significant differences between sites in regard to the body mass of beetles used for metal analysis $(p<0.002)$. Variables with $F>4.0$ were removed from the model (backward stepwise procedure). The percentage of total variance explained by the final regression models was expressed as $r^{2}$.

Because the beetles were collected from the same unpolluted site in 2008 and 2010, possible differences in energy reserve components between different years due to factors other than metal pollution were tested for using $t$ test. All statistical analyses were performed with Statgraphics Centurion XVI (StatPoint Technologies, Inc., USA).

\section{Results}

Among 120 measures of body $\mathrm{Zn}$ or $\mathrm{Cd}$ concentration at the OLK gradient, two values for $\mathrm{Cd}$ and two values for $\mathrm{Zn}$ were excluded from statistical analysis as outliers. For MSL $(n=207)$, ten outliers for body Cd concentration were excluded. Among 98 beetles analyzed for a particular component of energy reserves, one outlier was excluded from protein analysis and two from carbohydrate analysis, all from the MSL gradient. For technical reasons, the lipid contents were measured in 95 samples, and all samples were taken into account in further statistical analysis.

Both gradients covered a broad range of contamination levels, from virtually uncontaminated to highly contaminated with a mixture of metals. The highest concentrations of $\mathrm{Zn}$ and Cd were found near the Miateczko Ślaskie smelter (up to 2,906 and $55 \mathrm{mg} / \mathrm{kg}$, respectively, compared to the concentrations at the unpolluted site of $155 \mathrm{mg} \mathrm{Zn} / \mathrm{kg}$ and $2.2 \mathrm{mg}$ $\mathrm{Cd} / \mathrm{kg}$ ). The highest body concentrations of $\mathrm{Zn}$ were found in beetles collected from the Olkusz gradient $(107 \mathrm{mg} / \mathrm{kg}$ dry bw), whereas beetles collected near Miasteczko Śląkie smelter accumulated the highest concentrations of $\mathrm{Cd}(3.7 \mathrm{mg} / \mathrm{kg}$ dry bw). Detailed data on the metal concentrations in the soils and beetles are given in Table 1 . Both body $\mathrm{Zn}$ and $\mathrm{Cd}$ 
concentrations increased with increasing soil $\mathrm{Zn}$ and $\mathrm{Cd}$ concentrations $\left(p=0.003, r^{2}=67.9\right.$ and $p=0.0001, r^{2}=85.7$, respectively; Fig. 1). Although the relationship for $\mathrm{Zn}$ was significant, the range of average body $\mathrm{Zn}$ concentrations observed along contamination gradients was very narrow (95$107 \mathrm{mg} / \mathrm{kg}$ dry bw), indicating that the beetles are able to regulate $\mathrm{Zn}$ efficiently.

All energy reserve components exhibited large variation. Proteins and lipids were quantitatively the most important energy fractions in the biochemical composition of $P$. oblongopunctatus (992 to 1,748 J/g wet wt and 716 to $2,210 \mathrm{~J} / \mathrm{g}$ wet wt, respectively), whereas carbohydrates represented only 22 to $97 \mathrm{~J} / \mathrm{g}$ wet wt (Table 2).

Neither the energy reserves nor any of the energy reserve components (lipids, carbohydrates, and proteins) depended on the PI (Fig. 2). The only significant relationship was the increase in lipid fraction with body mass; the heavier beetles had more lipids per unit of body mass $(p=0.045$, $r^{2}=41.3 \%$ ). A significant difference was measured in the carbohydrates concentration between the means of the two unpolluted; beetles collected in 2010 had higher carbohydrate levels than those collected in $2008(p=0.016)$ (Fig. 2).

\section{Discussion}

With increasing levels of stress, the maintenance of physiological integrity becomes more difficult for organisms. Although energy-demanding homeostatic processes can initially provide comfort, they will eventually break down as soon as energy reserves become depleted (cf. Calow 1991; De Coen and Janssen 2003a), initiating a series of adverse effects. Thus, energy reserves provide valuable information about the capacity of an organism to cope with stress long before adverse effects are manifested at higher levels of biological complexity (Smolders et al. 2003). In this context, the energy status of $P$. oblongopunctatus was studied to gain insight into the costs of living in an environment with metal pollution. To enable strong and more
Fig. 1 Effect of metal concentration in soil on the internal body concentration of metals in P. oblongopunctatus collected along two pollution gradients. Upper panel, $\mathrm{Zn}$; lower panel, Cd; open circles, OLK; full circles, MSL
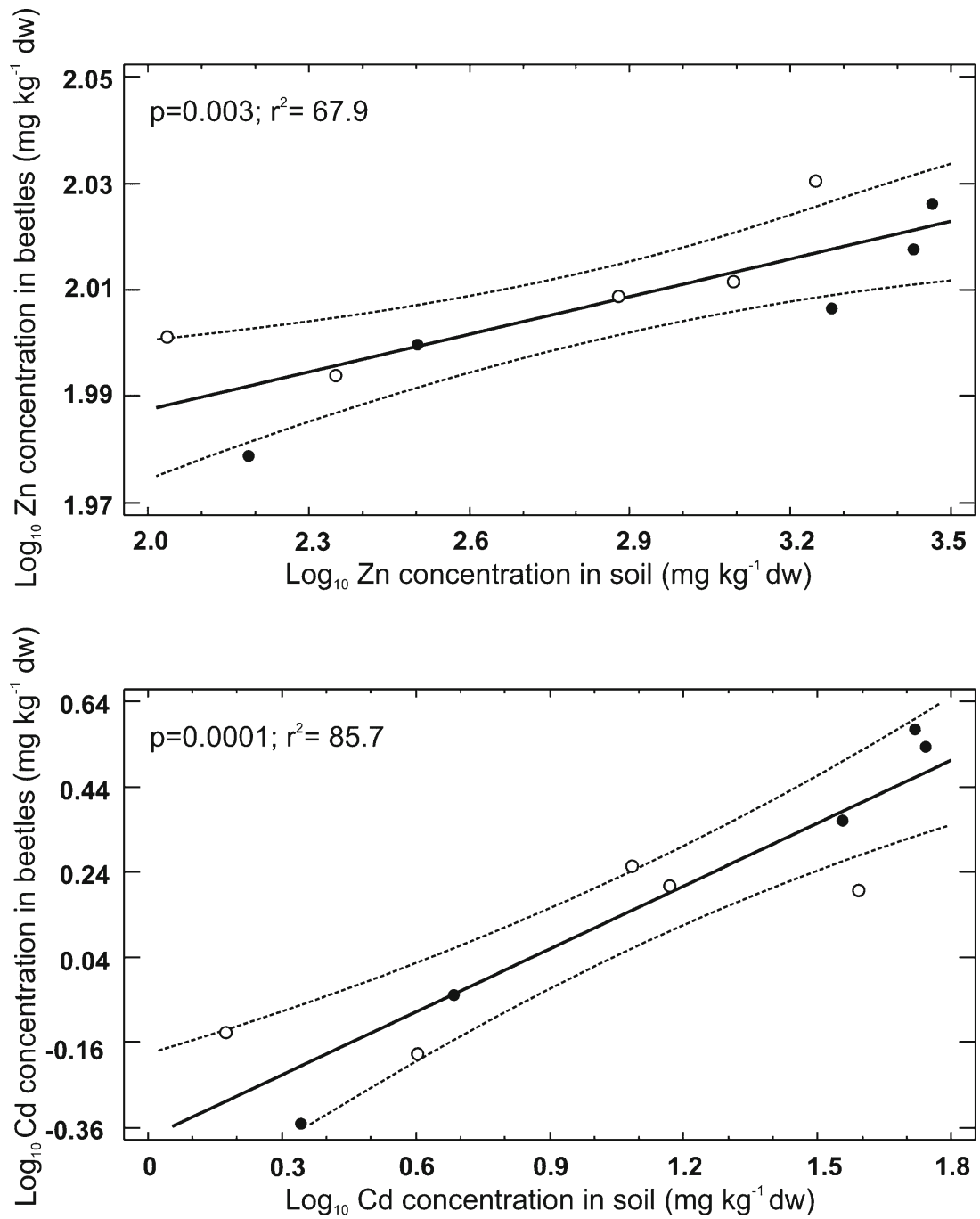
Table 2 Energy reserves (in joules per gram wet weight) in proteins, carbohydrates, and lipids and total energy reserves in the ground beetles $P$. oblongopuncatus (mean $\pm \mathrm{SD}$ ) collected along two metal pollution gradients

OLK Olkusz, MSL Miasteczko Śląskie

${ }^{\mathrm{a}}$ Number of beetles analyzed

\begin{tabular}{llllll}
\hline Transect & $\begin{array}{l}\text { Distance from } \\
\text { nearest } \\
\text { smelter }(\mathrm{km})\end{array}$ & Proteins & Carbohydrates & Lipids & Total energy reserves \\
\hline OLK & 3.9 & $1,644 \pm 386(9)^{\mathrm{a}}$ & $29 \pm 15.8(9)$ & $1,655 \pm 848(8)$ & $3,308 \pm 1,122(8)$ \\
OLK & 5.3 & $1,748 \pm 288(10)$ & $37 \pm 14.3(10)$ & $1,728 \pm 1,010(9)$ & $3,485 \pm 1,056(9)$ \\
OLK & 7.9 & $1,719 \pm 347(10)$ & $22 \pm 8.30(10)$ & $1,776 \pm 782(10)$ & $3,517 \pm 910(10)$ \\
OLK & 19.6 & $1,480 \pm 270(10)$ & $31 \pm 5.62(10)$ & $2,210 \pm 1,461(10)$ & $3,720 \pm 1,587(10)$ \\
OLK & 31.8 & $1,522 \pm 561(10)$ & $44 \pm 29.4(10)$ & $1,271 \pm 523(10)$ & $2,870 \pm 1,134(9)$ \\
MSL & 2.1 & $1,218 \pm 332(10)$ & $92 \pm 36.2(10)$ & $817 \pm 536(10)$ & $2,128 \pm 695(10)$ \\
MSL & 2.6 & $1,165 \pm 317(10)$ & $97 \pm 30.2(10)$ & $752 \pm 368(10)$ & $2,015 \pm 559(10)$ \\
MSL & 3.3 & $992 \pm 231(9)$ & $97 \pm 20.6(10)$ & $1,075 \pm 856(9)$ & $2,249 \pm 857(9)$ \\
MSL & 8.7 & $1,099 \pm 350(10)$ & $92 \pm 24.1(9)$ & $716 \pm 554(10)$ & $1,751 \pm 611(9)$ \\
MSL & 31.8 & $1,236 \pm 390(9)$ & $79 \pm 23.7(8)$ & $972 \pm 537(8)$ & $2,281 \pm 656(7)$ \\
\hline
\end{tabular}

general inference of the influence of metal pollution on energy reserves, and to exclude, as much as possible, other factors in the natural environment as a reason for possible differences in energy reserves between study sites, the research was carried out at two metal pollution gradients. The earlier study on closely related species Pterostichus melanarius indicated no correlation between sampling time and the percent of fat in beetles collected between April 1 and May 31 (Lindquist and Block 2001). However, at least some of the females were likely already fertilized (Brunsting 1981), and this is known to influence metabolism (Chaabane et al. 1999). Therefore, to avoid a large variation caused by sex-specific metabolism, as well as sex-specific differences in the accumulation of metals (Butovsky 2011), only males were used in this study.

No significant relationships between total energy reserves or the levels of their particular components and increasing metal concentration in the soil or beetles' bodies were found in this study. All biochemical fractions (proteins, carbohydrates, and lipids) exhibited large variation. A similarly large variation was observed in field-collected estuarine mysid Neomysis integer (Verslycke et al. 2004b). According to De Coen and Janssen (1997), each species has an individual available energy reserve distribution, and in the case of Daphnia magna, non-protein substrates are the preferred energy source. This study suggests that the main storage materials in $P$. oblongopunctatus are proteins and lipids, whereas carbohydrates were present at a relatively low level. The synthesis and utilization of energy reserves (i.e., fat and glycogen) are controlled in insects by fat body cells (Arrese and Soulages 2010). Much higher lipogenesis from glucose compared to glycogen synthesis explains the higher lipid content compared to glycogen in the insect body (Arrese and Soulages 2010) and may explain the high lipid content in P. oblongopunctatus. Glycogen is mobilized for the production of trehalose and sugar alcohols under suboptimal temperatures and drought and plays a role in preventing cellular damage at low temperatures and during diapause (Arrese and Soulages 2010). Studies of several insect species have shown that cold acclimation leads to an increase in the body content of trehalose and glucose (Storey 1990; Vanin et al. 2008). Therefore, the difference in carbohydrate concentration between beetles collected in 2008 and 2010 from unpolluted sites could be, at least partly, the consequence of a severe winter preceding sampling in 2010. Analysis of meteorological data from the Research Station of the Institute of Geography and Spatial Management in GaikBrzezowa (Wieliczka Foothills) revealed that the average daily minimum and maximum air temperature during winter (31st December-31st March) were lower in 2010 ( -4.3 and $2.3^{\circ} \mathrm{C}$, respectively) compared to 2008 ( -0.8 and $5.7^{\circ} \mathrm{C}$, respectively).

Considering the components of available energy reserves, proteins are indicated as a prominent element for building enzymes, hormones, and antibodies in organisms, whereas glycogen and lipid reserves are used preferably to proteins in response to stress (Smolders et al. 2003). However, different species can use different strategies to survive in heavily metal-contaminated areas, and various effects of metals on energy reserves in terrestrial invertebrates have been reported. Donker (1992) showed that the isopod Porcelio scaber collected from metal-polluted areas with remarkably high $\mathrm{Zn}$ and $\mathrm{Cd}$ concentrations in their bodies have reduced energy reserves (i.e., protein, glycogen, and lipid content). On the other hand, neither glycogen nor total protein content in $P$. scaber collected from contaminated or uncontaminated sites were diminished by exposure to lead in the laboratory (Knigge and Köhler 2000). Schill and Köhler (2004) showed that the glycogen and lipid content of midgut gland cells from $P$. scaber did not depend on the distance from the pollution source in animals collected from long-term polluted sites in the vicinity of a lead-zinc smelter 

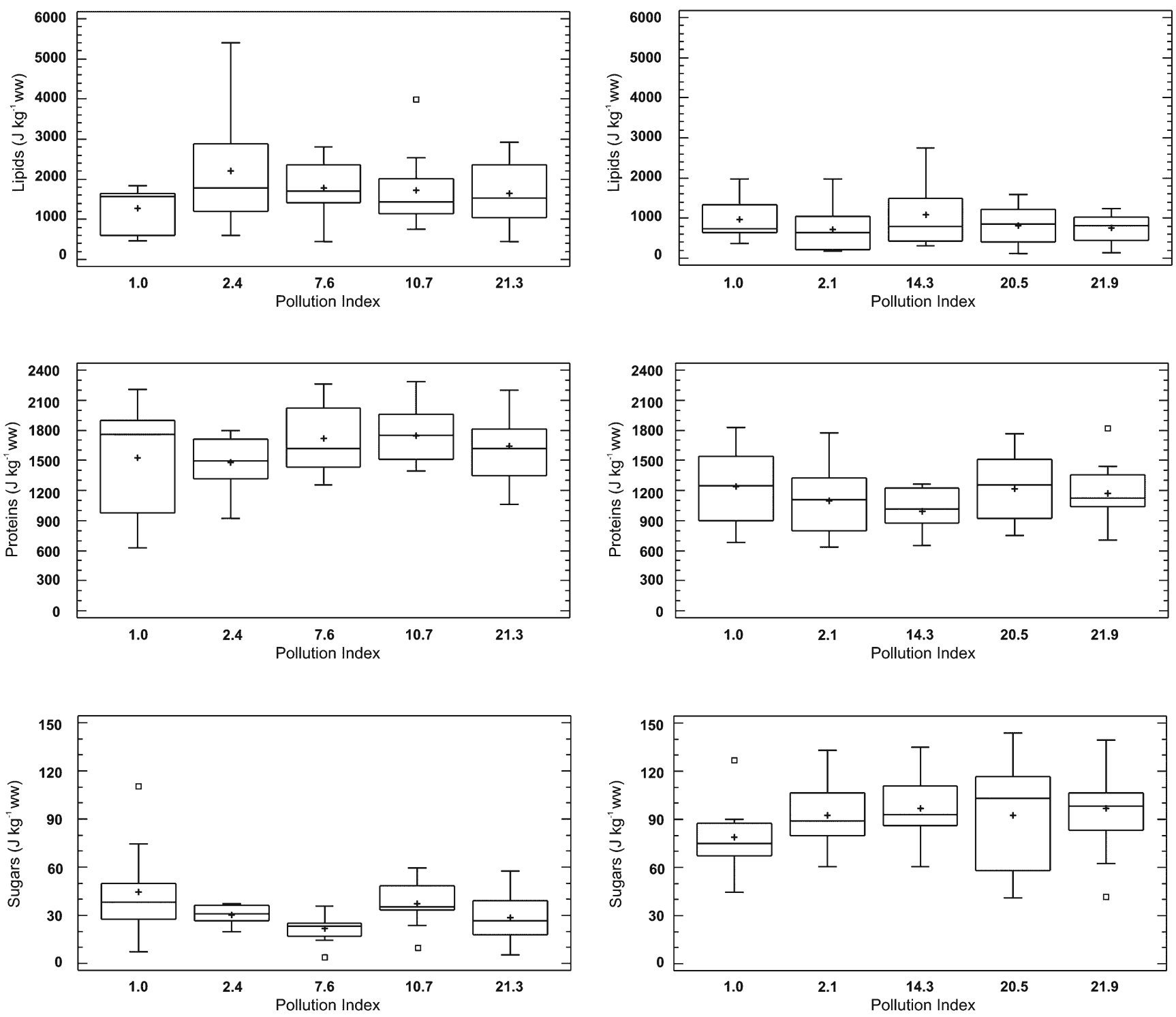

Fig. 2 Box-and-whisker plots for energy reserves (proteins, lipids, and carbohydrates) in $P$. oblongopunctatus collected from sites with different pollution indices at the OLK (left hand column) and MSL gradients (right hand column). The plus sign on each box represents the mean

in Avonmouth, UK. Also, Holmstrup et al. (2011) did not find any correlation between internal $\mathrm{Cd}$ or $\mathrm{Pb}$ concentrations and glycogen reserves in earthworms (Dendrobaena octaedra), despite high body concentrations of metals. In contrast to the metals occurring at high internal concentrations, metals that are regulated by earthworms and kept at low levels $(\mathrm{Ni}, \mathrm{Al}$, and in one case, also $\mathrm{Zn}$ ) caused a reduction in glycogen reserves. The authors concluded that the detoxification of metals by storage in granules as inert precipitates, as in the case of $\mathrm{Pb}$ and $\mathrm{Cd}$, seems to be associated with decreased energy demands compared to active regulation of internal concentrations $(\mathrm{Ni}, \mathrm{Al})$ by the worms. Undoubtedly, also beetles are able to regulate concentrations of nutritional metals more efficiently than those

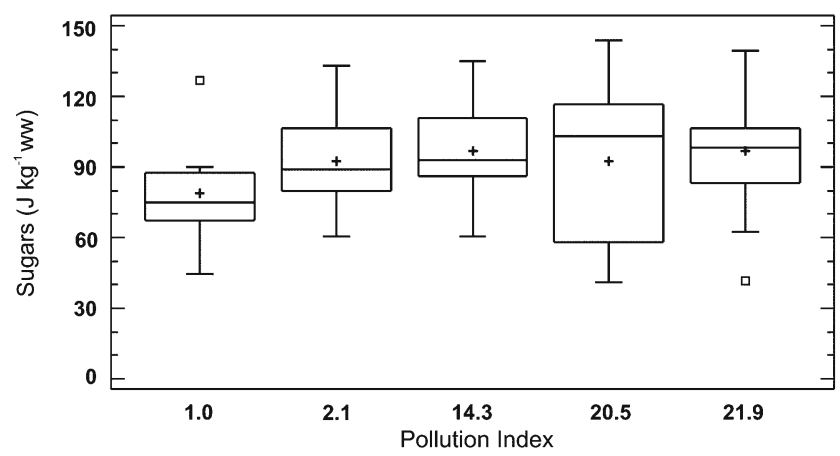

value, the center line shows the sample median, the boxes contain lower and upper quartiles, and the whiskers extend to the minimum and maximum values. The most extreme values outside this range are shown as small squares

of xenobiotic metals (Kramarz 1999; this study). The storage of metals as an energy efficient method of detoxification and subsequent excretion via feces was earlier suggested by Simkiss $(1976,1977)$.

To verify that metal pollution has an effect on the energy content of the body, Zygmunt et al. (2006) measured the body caloric value of $P$. oblongopunctatus but found no relationship with the level of metal contamination in the soil. Another study aimed at assessing the energy reserves of Poecilus cupreus, a carabid species closely related to the one studied in this paper, used the caloric value of the organism as an indicator of stress (Maryański et al. 2002). The authors showed a decrease in the body caloric value with increasing food contamination. However, the results 
were obtained in a laboratory experiment with laboratoryreared animals fed with artificially contaminated food and kept individually under optimal conditions; thus, any confounding factors, such as competition, were excluded. This observation may suggest that ecological interactions, such as decreased competition for resources at polluted sites, can counterbalance the costs of detoxification.

Different resistance mechanisms have different theoretical costs (Coustau et al. 2000), and the indirect evidence that carabids bear the costs of living in a polluted environment can be deduced from a decline in the fertility of female beetles from more contaminated sites (Lagisz et al. 2002) and lower quality of produced eggs (Lagisz and Laskowski 2008). Stone et al. (2001) showed that $P$. oblongopunctatus inhabiting chronically metal-polluted sites were less tolerant to additional environmental stressors (e.g., food deprivation or pesticide) than those from less contaminated areas. Further study of this species did not reveal the genetic basis of this increased susceptibility to additional stressors (Lagisz and Laskowski 2007). Metal resistance often involves an increased production of ligands, proteins, and enzymes involved in detoxification, which must bear some costs. Therefore, a reduction in an animal's energy reserves or increases in their metabolic rates have been associated with metal toxicity (Moolman et al. 2007). Although many short-term studies on aquatic invertebrates have shown that energy reserves are sensitive endpoints that respond rapidly to chemical stressors (De Coen and Janssen 2003a; Smolders et al. 2004), the depletion of energy reserves was seldom found in terrestrial invertebrates exposed in situ (Donker 1992).

\section{Conclusion}

P. oblongopunctatus are able to survive in metal-polluted environments without any serious impact on their energy reserves, though they obviously have to cope with high body metal concentrations. The energy reserves of the studied carabids were remarkably stable, independent of the pollution. The mechanisms that endow the $P$. oblongopunctatus from metalpolluted areas with resistance to metal toxicity remain unclear.

\footnotetext{
Acknowledgments We thank R. Śliwińska for her help in the field. We also thank R. Laskowski for his advice during the study and useful suggestions that improved the manuscript. Financial support was provided by the Polish Ministry of Science and Higher Education (Project No. N N304 025134) and Jagiellonian University (DS 759). A.J. Bednarska was sponsored by the Foundation for Polish Science, START Programme.

Open Access This article is distributed under the terms of the Creative Commons Attribution License which permits any use, distribution, and reproduction in any medium, provided the original author(s) and the source are credited.
}

\section{References}

Arrese EL, Soulages JL (2010) Insect fat body: energy, metabolism, and regulation. Annu Rev Entomol 55:207-225

Bradford MM (1976) A rapid and sensitive method for the quantification of microgram quantities of protein, utilizing the principle of protein-dye landing. Anal Biochem 72:248-254

Brunsting AMH (1981) Distribution patterns, life cycle and phenology of Pterostichus oblongopunctatus F. (Col., Carabidae) and Philonthus decorus grav. (Col., Staphylinidae). Neth J Zool 31:418452

Butovsky RO (2011) Heavy metals in carabids (Coleoptera, Carabidae). In: Kotze DJ, Assmann T, Noordijk J, Turin H, Vermeulen R (ed) Carabid beetles as bioindicators: biogeographical, ecological and environmental studies. ZooKeys 100:215-222

Calow P (1991) Physiological costs of combating chemical toxicants: ecological implications. Comp Biochem Physiol 100C:3-6

Chaabane K, Josens G, Loreau M (1999) Respiration of Abax ater (Coleoptera, Carabidae): a complex parameter of the energy budget. Pedobiologia 43:305-318

Coustau C, Chevillon C, Ffrench-Constant R (2000) Resistance to xenobiotics and parasites: can we count the cost? Trends Ecol Evol 15:378-383

De Coen WM, Janssen CR (1997) The use of biomarkers in Daphnia magna toxicity testing. IV. Cellular energy allocation: a new methodology to assess the energy budget of toxicant-stressed Daphnia populations. J Aquat Ecosyst Stress Recov 6:43-55

De Coen WM, Janssen CR (2003a) The missing biomarker link: relationships between effects on the cellular energy allocation biomarker of toxicant-stressed Daphnia magna and corresponding population characteristic. Environ Toxicol Chem 22:1632-1641

De Coen WM, Janssen CR (2003b) A mulrivariate biomarker-based model predicting population-level responses of Daphnia magna. Environ Toxicol Chem 22:2195-2201

Donker MH (1992) Energy reserves and distribution of metals in populations of the isopod Porcelio scaber from metal-polluted sites. Funct Ecol 6:445-454

Erk M, Muyssen B, Ghekiere A, Janssen CR (2008) Metallothionein and cellular energy allocation in the estuarine mysid shrimp Neomysis integer exposed to cadmium at different salinities. J Exp Ma Biol Ecol 357:172-180

Gnaiger E (1983) Calculation of energetic and biochemical equivalents of respiratory oxygen consumption. In: Gnaiger E, Forstner $\mathrm{H}$ (eds) Polarographic oxygen sensors. Aquatic and physiological applications. Springer, Berlin, pp 337-345

Holmstrup M, Sørensen JG, Overgaard J, Bayley M, Bindesbøl AM, Slotsbo S, Fisker KV, Maraldo K, Waagner D, Labouriau R, Asmund G (2011) Body metal concentrations and glycogen reserves in earthworms (Dendrobaena octaedra) from contaminated and uncontaminated forest soil. Environ Pollut 159:190 197

Hopkins WA, Rowe CL, Congdon JD (1999) Elevated trace element concentrations and standard metabolic rate in banded water snakes (Nerodia fasciata) exposed to coal combustion wastes. Environ Toxicol Chem 18:1259-1263

Janssen MPM, Bruins A, de Vries TH, Van Straalen NM (1991) Comparison of cadmium kinetics in four soil arthropod species. Arch Environ Contam Toxicol 20:305-312

Kemp A, Kits van Heijningen AJM (1953) A colorimetric micromethod for determination of glycogen in tissues. Biochem $\mathrm{J}$ 56:646-648

Khalil MA, Donker MH, Van Straalen NM (1995) Long-term and short-term changes in the energy budget of Porcellio scaber Latreille (Crustacea) exposed to cadmium polluted food. Eur J Soil Biol 31:165-172 
Knigge T, Köhler HR (2000) Lead impact on nutrition, energy reserves, respiration and stress protein (hsp 70) level in Porcellio scaber (Isopoda) populations differently preconditioned in their habitats. Environ Pollut 108:209-217

Kramarz P (1999) Dynamics of accumulation and aecontamination of cadmium and zinc in carnivorous invertebrates. 1. The ground beetle, Poecilus cupreus L. Bull Environ Contam Toxicol 63:531-537

Lagisz M, Laskowski R (2007) Susceptibility of a carabid beetle, Pterostichus oblongopunctatus Fab., from a gradient of heavy metal pollution to additional stressors. Bull Environ Contam Toxicol 79:504-507

Lagisz M, Laskowski R (2008) Evidence for between-generation effects in carabids exposed to heavy metals pollution. Ecotoxicology 17:59-66

Łagisz M, Kramarz P, Laskowski R, Tobor M (2002) Population parameters of the beetle Pterostichus oblongopunctatus F. from metal contaminated and reference areas. Bull Environ Contam Toxicol 69:243-249

Laskowski R, Maryański M (1993) Heavy metals in epigeic fauna: thropic-level and physiological hypotheses. Bull Environ Contam Toxicol 50:232-240

Laskowski R, Pyza E, Maryański M, Niklińska M (1998) Test on the centipede Lithobius mutabilis L. Koch 1852 (Chilopoda: Lithobiidae). In: Løkke H, Van Gestel CAM (eds) Handbook of Soil Invertebrate Toxicity Tests. John Wiley and Sons, Chichester, pp $181-196$

Lindquist L, Block M (2001) Metal pollution and fat accumulation in the carabid beetle Pterostichus melanarius (Coleoptera, Carabidae). Bull Environ Contam Toxicol 66:184-188

Maryański M, Kramarz P, Laskowski R, Niklińska M (2002) Decreased energetic reserves, morphological changes and accumulation of metals in carabid beetles (Poecilus cupreus L.) exposed to zinc- or cadmium-contaminated food. Ecotoxicology 11:127139

Moolman L, Van Vuren JHJ, Wepener V (2007) Comparative studies on the uptake and effects of cadmium and zinc on the cellular energy allocation of two freshwater gastropods. Ecotox Environ Safe 68:443-450

Pook C, Lewis C, Galloway T (2009) The metabolic and fitness costs associated with metal resistance in Nereis diversicolor. Mar Pollut Bull 58:1063-1071

Posthuma L, Van Straalen NM (1993) Heavy-metal adaptation in terrestrial invertebrates: a review of occurrence, genetics, physiology and ecological consequences. Comp Biochem Physiol 106C:11-38

Rowe CL, Kinney OM, Nagle RD, Congdon JD (1998) Elevated maintenance costs in an anuran (Rana catesbeiana) exposed to a mixture of trace elements during the embryonic and early larval periods. Physiol Zool 71:27-53

Schill R, Köhler HR (2004) Energy reserves and metal-storage granules in the hepatopancreas of Oniscus asellus and Porcellio scaber (Isopoda) from a metal gradient at Avonmouth, UK. Ecotoxicology 13:787-796
Scott-Fordsmand JJ, Weeks JM (2000) Biomarkers in earthworms. Rev Environ Contam T 165:117e159

Sibly RM, Calow P (1989) A life-cycle theory of responses to stress. Biol J Linn Soc 37:101-116

Simkiss K (1976) Intracellular and extracellular routes in biomineralization. Symp Soc Exp Biol 30:423-444

Simkiss K (1977) Biomineralization and detoxification. Calcif Tiss Res 24:199-200

Skalski T, Gargasz K, Laskowski R (2011) Does mixed diffused pollution decrease ground beetle diversity? Baltic J Coleopterol 11:1-15

Smolders R, De Boeck G, Blust R (2003) Changes in cellular energy budget as a measure of whole effluent toxicity in zebrafish (Danio rerio). Environ Toxicol Chem 22:890-899

Smolders R, Bervoets L, De Coen W, Blust R (2004) Cellular energy allocation in zebra mussels exposed along a pollution gradient: linking cellular effects to higher levels of biological organization. Environ Pollut 129:99-112

Spurgeon DJ, Hopkin SP (1999) Seasonal variation in the abundance, biomass and biodiversity of earthworms in soils contaminated with metal emissions from a primary smelting works. J Appl Ecol 36:173-183

Stefanowicz AM, Niklińska M, Laskowski R (2008) Metals affect soil bacterial and fungal functional diversity differently. Environ Toxicol Chem 27:591-598

Stone D, Jepson P, Kramarz P, Laskowski R (2001) Time to death response in carabid beetles exposed to multiple stressors along a gradient of heavy metal pollution. Environ Pollut 13:239-244

Storey K (1990) Biochemical adaptation for cold hardiness in insects. Phil Trans R Soc Lond B 326:635-654

Stürzenbaum SR, Kille P, Morgan AJ (1998) Heavy metal-induced molecular responses in the earthworm, Lumbircus rubellus genetic fingerprinting by directed differential display. Appl Soil Ecol 9:495-500

Tarasek A (2011) Heavy metal effect on activity and functional diversity of soil microbial communities in Miasteczko Śląskie area. Dissertation, Jagiellonian University (in Polish)

Vanin S, Bubacco L, Beltramini M (2008) Seasonal variation of trehalose and glycerol concentrations in winter snow-active insects. Cryo Lett 29:485-491

Verslycke T, Roast SD, Widdows J, Jones MB, Janssen CR (2004a) Cellular energy allocation and scope for growth in the estuarine mysid Neomysis integer (Crustacea: Mysidacea) following chlorpyrifos exposure: a method comparison. J Exp Ma Biol Ecol 306:1-16

Verslycke T, Ghekiere A, Janssen CR (2004b) Seasonal and spatial patterns in cellular energy allocation in the estuarine mysid Neomysis integer (Crustacea: Mysidacea) of the Scheldt estuary (The Netherlands). J Exp Ma Biol Ecol 306:245-267

Zygmunt PMS, Maryański M, Laskowski R (2006) Body mass and caloric value of the ground beetle (Pterostichus oblongopunctatus) (Coleoptera, Carabidae) along a gradient of heavy metal pollution. Environ Toxicol Chem 25:2709-2714 